\title{
THE MANAGEMENT OF PROCUREMENT OF GOODS AT A LOGISTICAL BASE
}

\author{
Valentin PÎRVUȚ \\ “Nicolae Bălcescu” Land Forces Academy, Sibiu, Romania
}

\begin{abstract}
The logistical bases are large units of logistical support which are composed of specialized logistical units that can be in the subordination of infantry divisions and of the branches of the army/command units. One of the most important tasks assigned to the base is representd by procurement of goods, services and works in accordance with the legal competences, or delegated by the secondary credit release authority. At the level of a logistical base, the management of public acquisitions represents a complex process, coordinated by the commandant and run by the structure of acquisitions or the corresponding micro-structure within the logistical department, which aims at providing the functional, economic and judicial framework, necessary for initiating, carrying on and finalizing the organized procedures with a view to satisfying its own needs and of the assigned units.
\end{abstract}

\section{Keywords: procurement, goods, logistics, main credit release authority, provision}

\section{Introduction}

The logistical support represents the totality of activities that are carried out by the logistical structures, having the purpose of providing the forces with all the supplies that are necessary for taking the military actions.

The logistical support that a logistical base ensures has in view the following functional fields: supply; movement and transportation; maintenance; infrastructure; campaign services; purchasing contracts; provision of food; related fields.

Procurement is a component part/domain of the logistics of troops that includes the totality of the activities that are fulfilled in order to establish the amount, the launching of the demand, the development of the acquisition procedures, the reception, management, storage, delivery of material goods which are necessary for the equipment and support of forces in taking the military actions. This activity is accomplished in the form of classes or subclasses of supply [1].

Procurement is organized in a unitary conception, comprising the specific activities of planning, coordinating, record keeping and distribution/allocation of material resources supplied on the basis of the commandant's decision and of the order for logistics, issued by the logistical structure personnel.

The main objectives of procurement are:

a) the timely provision of the regular amounts of consumption at the level of demand, in order to meet the preestablished level of training and maintain the combat readiness of the armed forces;

b) the setting up and completion of stocks;

c) provision of spare parts and materials necessary for maintenance, for maintaining in operational deployment the military equipment.

In order to elaborate efficient strategies of procurement, several elements must be taken into consideration as they can influence the provision of the acquiring military units in their position of contracting authorities. 
These concrete elements must be known, interpreted and analysed correctly. We enumerate among them [2]:

- the availabilities existing on the market - whether the goods that are to be acquired are in sufficient supply on the market, then the liberty of action of the military unit is great and the other way round;

- number of bidders - the bigger the number, the greater the selection possibilities at the disposal of the acquirer, giving him the chance to obtain a better price;

- agreement among bidders - it is forbidden to abusively use a dominant position held by one or by several economic operators, by resorting to anti competitive acts which can have an impact on trade or can prejudice the consumers (hence the procurement opportunities of the military unit are also affected);

- $\quad$ the prices used by bidders - the greater the number of bidders, the better the prices for the acquiring unit, and the other way round;

- the financial capacity of the bidder the more a bidder has his own financial means, the more he can acquire raw materials, as well as materials necessary for achieving military products or common products that are found in the national economy, and the risk of not integrally purchasing the contract is diminished;

- integral production upstream - cu cât ofertantul realizează mai multe subansamble, cu atât probabilitatea realizării prevederilor contractual este mai mare; the more subassemblies the bidder obtains, the greater the probability of achieving the contract provisions;

- the position on the market of the purchasing legal entity - is influenced by its prestige, by the available financial resources, by the quantity of the goods that are being purchased.

Thus, taking into consideration the above- mentioned aspectd, the acquisitions, the purchasing contracts become a significant instrument used for obtaining access to the local resources and to other necessary materials and services, playing an increasing role in managing the joint operations. These acquisitions are carried out by complying with the European legislation provisions, translated into the O.U.G. text no.34/ 2006, with the subsequent modifications and completions, as well as into the O.U.G. text no.114/ 2011.

\section{Particularities related to acquisitions based on competences}

For the carrying out of public acquisitions of goods, services and works within the Ministry of National Defense, the structures in its composition, whose leaders have the position of credit release authorities and are assigned competences of acquisition, are delegated purchasing authorities, with responsibilities established by the legislation in force for the purchasing authority [3].

With a view to increasing the efficiency of utilizing the public funds and improving the process of procurement within the Ministry of National Defense, the purchasing of goods, services and works is done as follows[4]:

- centralized, at the level of the Ministry of National Defense:

a) for the logistics of production:

- by the specialized structures/ Departament for armaments, for armament systems/ majorechipament and related logistical support;

- by the specialized structures/CCI - for national military networks of communication, computer systems and related logistical support;

b) for the consumption logistics - by all the logistical bases and CLI, and by thespecialized structures/Medical Department, Department of fields and infrastructures, for equipment and materials in the specific field, other than the ones included in the competency of the Departament for armaments or CCI, as well 
as for the services necessary for the running of the regular activities of the army;

- descentralizat, for the consumption logistics by all the logistical territorial bases/CLI and the logistical structures of the military units, for the other products, services and works which are not included in the centralized system of procurement, in accordance with the regulations regarding the acquisitions competences and with the provisions made by the higher echelon.

Aşa cum se poate observa, baza logistică execută achiziţii atât centralizat cât şi descentralizat. Alegerea uneia din cele două opţiuni este impusă de complexitatea achiziţiei, valoarea estimată a acesteia, limita competenţelor sau strategia de achiziţie gândită la nivelul eşaloanelor superioare (ordonatorului secundar de credite).

As can be noticed, the logistical base purchases goods both in a centralized and a descentralized way.

The logistical structures that have responsibilities in planning, managing, executing and evaluating the public acquisitions activities, at the level of the logistical base command unit, as well as at the level of the higher echelon, order the centralization of acquisitions, having in view to obtain a maximum level for the quality of products and advantageous costs for services.

Starting from the above-mentioned aspects, we will further try to present some of the advantages of the centralized acquisition:

- the necessary period of time is diminished, as well as the number of structures involved in carrying out the tasks of purchasing;

- it provides advantages for the Ministry of Defense in terms of the unitary price of acquisition, its cumulated volume being much above the one corresponding to the necessary amount identified at the level of each beneficiary unit, so creating conditions for obtaining better offers;

- the experience of the personnel working in the acquisition structures of the logistical bases is turned to good account;

- it ensures the compliance of the principle the efficiency of using public funds", as is stipulated in article 2, paragraph 2, letter $f$ of the O.U.G. no. 34/ 2006, with the subsequent modifications and completions, through the elimination of expenses related to organizing acquisition by each unit, as well as through practicing smaller acquisition unitary prices, corresponding to larger quantities;

- it allows an easy monitorization of the running of the acquisition procedures.

\section{Elements of founding the decision in the activity of public acquisitions}

In the practice of public acquisitions, most decisions are taken in conditions of risk. The person responsible for the procedure follows an estimated calendar, but he is not in the position of appreciating how long the checking in advance of the assignment documentation in the ANRMAP will last, he does not know the exact date of the announcement publication/invitation of participation, he does not have the certitude that the documentation is not contested, after publication, by another economic operator, or even worse he cannot know precisely whether an offer or application will be made for the selected procedure. Although the information is not complete, the managers of the acquisitions structures can calculate the likelihood of the emergence of some events, as well as their effects, and then they select the most favorable version. In determining these probabilities, of great use prove to be the history record of the acquisitions structures, the legal stages that have to be followed both by the purchasing authority and by the economic operators, and not in the least the experience of the workers in the field. The decision-making processes share common elements in spite of their variety, which are manifested in a succession of activities, of stages that can form an algorithm of the decision. In the activity of acquisitions there are certainly certain stages that are 
carried out, the decisions that the decisionmaker must make (the manager of the purchasing authority or the chief of the acquisitions structure) have the following pattern: defining the problem that requires finding a solution in a certain time interval; enumerating possible versions/alternatives of action; collecting the information that can help the estimation of the effects of the versions that are considered; identifying the most favorable version by comparing and evaluating these versions taken into consideration on the basis of several criteria and priorities; developing and implementing the selected version; evaluating the final results and making necessary corrections, if any. These are the six stages of the $\boldsymbol{D E} \boldsymbol{C I D E m o d e l ~ [ 5 ] , ~ b y ~}$ which a decision-making process can be explained, irrespective of its nature.Admittedly, the concrete situations can lead to an increase or a decrease in the complexity of the decision-making process in the activity of procurement, which makes the sequence of these stages to be not as rigurously followed.

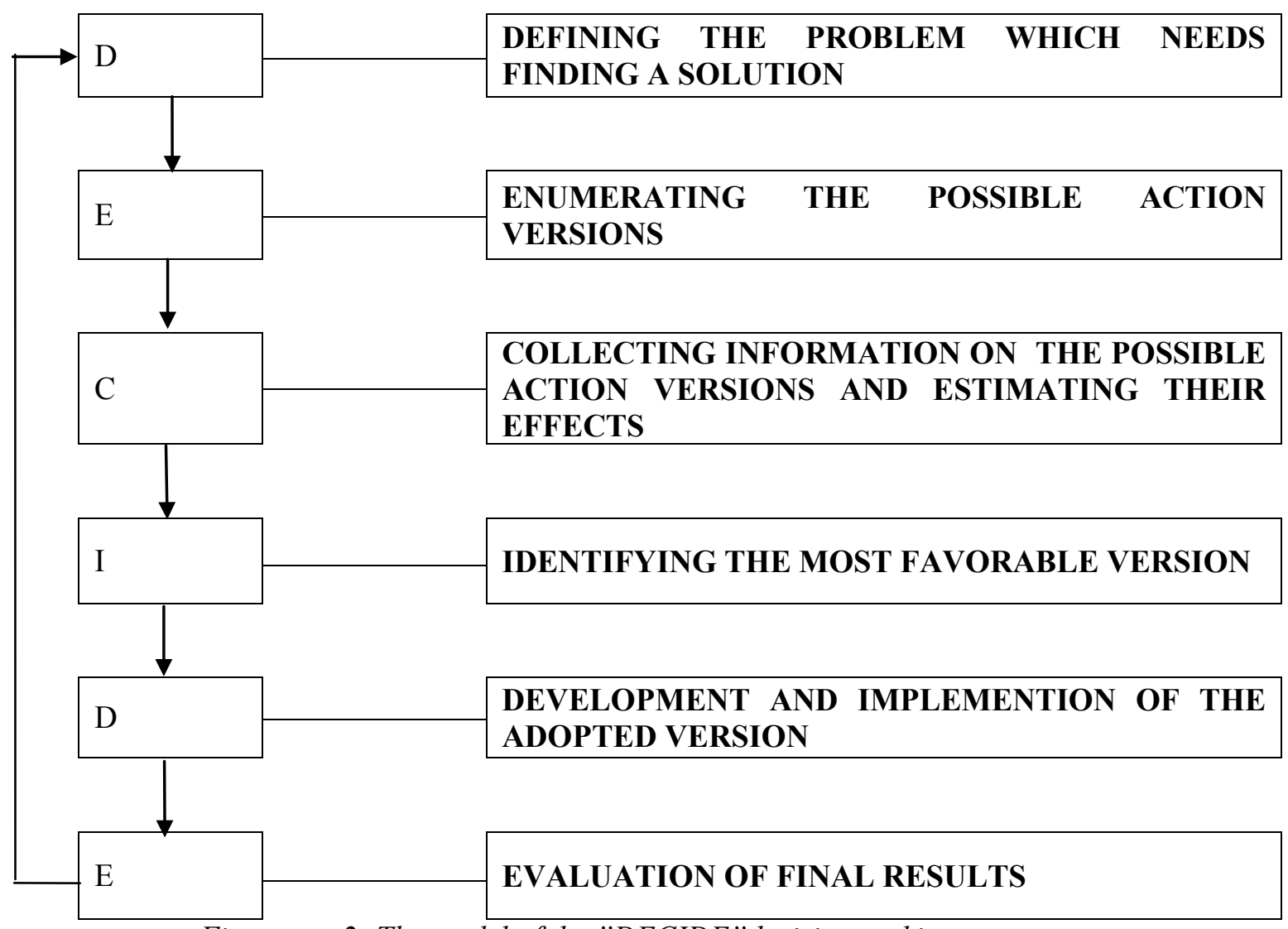

Figure no. 2: The model of the "DECIDE"decision-making process

The chief of the acquisitions structure analyses the whole process and proposes the correction of certain negative aspects, if any. He also has in view the elements regarding the transmission of stipulations for signing subsequent contracts, especially the process of taking over the measuring groups (gauges) and reading the amounts used up by the new natural gas supplier untill the starting point.

\section{Conclusions}

Romania's army has the mission to defend and promote the national security interests of the country. As a NATO member country, it also participates and will participate in peace-keeping operations and in managing crises in different parts of the globe. In this context, making efficient the system of acquisitions in the military field, providing the armed forces with modern and cutting-edge equipment is one of major directions in the military transformation 
process.

In the current context, approaching this issue aimed at facilitating understanding the process of public procurement in general, focusing on the aspects related to the managerial practice occurring at the level of a logistical base.

Our intentions in writing the paper are reflected in the initial objectives to be attained by this endeavour, as follows:

- a good understanding of the system of public acquisitions in Romania's army, particularly within a Logistical Base;

- bringing into relief the importance of public acquisitions within the system of logistical support;

- maintaining the rigorousness in the the system of public acquisitions, which allows for the achievement of the objectives of the military organization menţinerea rigurozităţii sistemului de achiziţii publice, fapt ce permite realizarea la un nivel superior a obiectivelor organizaţiei militare în ceea ce priveşte asigurarea sprijinului logistic;

- the elaboration and presention during practical applications of certain models of documentation for initiating and carrying out of an auction with a supplementary "electronic" stage, which can form a guide for the new employee within a public acquisition structure;

- the formulation of conclusions and proposals regarding the improvement of the activity of public acquisitions.

Having as a purpose to highlight certain concrete aspects, we focused on describing the public acquisitions management in a logistical base and showed, on the basis of our own experience in the field, how the system of relationships works, presenting the elements in the foundation of decision, as well as a practical example.

As a subsystem of the Romanian society, one can state that the army "suffers" as much as the other subsystems, in the effort to overcome the present conditions of economic crisis. The incertitude and the austerity budgets further make that certain procedures of public acquisition to be finalized with framework agreements, not with purchasing contracts. On the other hand, starting from the conviction that man is the measure of all things in the military system too, we strongly believe that the power, the solutions will come from the inside.

In order to improve the activity in the field of public acquisitions, we consider of great importance the creation of a legal system for enhancing the attractiveness for the positions in the field of public acquisitions. Thus, the decision-makers should have in mind financial motivations, the reactivation of the system of compensations, the recognition of merits and, last but not least, plans for insuring the future.

The professional workers in the field of public acquisitions can get their training and qualification in hard enough conditions, but once they are trained, the risks pertaining to this field are considerably reduced, therefore the managers of military organizations should channel their efforts in the direction of keeping them.

\section{References}

[1] Ordinul nr. 36/2008, pentru aprobarea L1 - Regulamentului logisticii operaţiilor întrunite, publicat în Monitorul Oficial, Partea I, nr. 353 din 07/05/2008.

[2] Bălăşan, G., Pricop, M. - Managementul aprovizionării şi desfacerii, Economică Publishing House, Bucureşti, 2004, p.26.

[3] Ordinul nr. M.31 din 25 martie 2008, privind competenţele de achiziţie a produselor, serviciilor şi lucrărilor în cadrul Ministerului Apărării (Publicat în Monitorul Oficial nr. 269 din 4 aprilie 2008), completat cu Ordinul nr. M.21 din 23 februarie 2009.

[4] Strategia Logisticii Armatei României / 2009.

[5] Virgil Balaure (coordinator) - Marketing, UranusPublishing House, Second Edition, Bucharest 2002, p.565. 